\begin{tabular}{|l|l|l|l|l|l|l|l|l|l|l|ll|l|}
\hline & $\mathbf{C}$ & $\mathbf{D}$ & $\mathbf{E}$ & $\mathbf{V}$ & & $\mathbf{1}$ & $\mathbf{6}$ & $\mathbf{3}$ & $\mathbf{7}$ & $\mathbf{R}$ & Dispatch: 29.7.11 & Journal: CDEV & CE: Anusha \\
\cline { 1 - 3 } \\
\hline
\end{tabular}

Child Development, xxxxx 2011, Volume 00, Number 0, Pages 1-13

\title{
Social Groups and Children's Intergroup Attitudes: Can School Norms Moderate the Effects of Social Group Norms?
}

\author{
Drew Nesdale and Michael J. Lawson \\ Griffith University
}

\begin{abstract}
The effects of social group norms (inclusion vs.exclusion vs. exclusion-plus-relational aggression) and school norms (inclusion vs. no norm) on 7- and 10-year-old children's intergroup attitudes were examined. Children

$2(n=383)$ were randomly assigned to a group with an inclusion or exclusion norm, and to one of the school norm conditions. Findings indicated that children's out-group attitudes reflected their group's norm but, with increasing age, they liked their in-group less, and the out-group more, if the group had an exclusion norm. The school inclusion norm instigated more positive attitudes toward out-group members, but it did not moderate or extinguish contrary group norms. The use of school norms to counteract the effects of children's social group norms is discussed.
\end{abstract}

A considerable amount of research has examined children's intergroup prejudice (see Aboud, 1988; Brown, 1995; Nesdale, 2001; for reviews), and a number of theories have been proposed to account for it (e.g., Aboud, 1988; Abrams \& Rutland, 2008; Bigler \& Liben, 2007; Nesdale, 2007. Central to the present research was the latter approach, social identity development theory (SIDT), which argues that young children's intergroup attitudes are significantly influenced by their identification with particular social groups, especially when those groups have norms that endorse out-group prejudice (Nesdale, 2007).

One aim of the present study was to assess this claim by varying the social acceptability of the ingroup's norm (i.e., inclusion and friendliness toward others, vs. exclusion and unfriendliness toward others, vs. exclusion-plus-relational aggression toward others) and examining its influence on the participants' intra and intergroup attitudes. The second aim was to examine the effect on the children's attitudes of a school norm (i.e., inclusion and friendliness toward others, vs. no school norm). The third aim was to determine whether a school norm of inclusion would moderate a group norm of exclusion. The final aim was to assess

This research was supported by an Australian Research Council Discovery Grant (DP0664691) to the authors.

Correspondence concerning this article should be addressed to Drew Nesdale, School of Psychology, Gold Coast Campus, Griffith University, Southport, Queensland, Australia. Electronic mail may be sent to d.nesdale@griffith.edu.au. whether the preceding effects would differ as a function of the age ( 7 vs. 10 years of age) of the participants.

\section{Social Identity Development Theory}

Social identity development theory (SIDT, Nesdale, 2007) was framed in response to research indicating that, from the commencement of schooling, middle childhood is increasingly marked by children's involvement in social groups or cliques and that much of their social interaction during this period takes place in the context of these groups (Rubin, Bukowski, and Parker (1998). Such findings are consistent with the view that children have a fundamental need to be accepted and to belong (Baumeister \& Leary, 1995), and that children's group memberships are an integral part of their self-concepts (Bennett \& Sani, 2008).

On this basis, SIDT proposes that intergroup prejudice is the end point of a process that involves four sequential phases: undifferentiated (typically, up to 2-3 years), group awareness (beyond 2-3 years), in-group preference (after acquisition of group awareness), and out-group prejudice (typically, after 6-7 years in those children who become prejudiced). These phases

(C) 2011 The Authors

Child Development (C) 2011 Society for Research in Child Development, Inc. All rights reserved. 0009-3920/2011/xxxx-xxxx

DOI: $10.1111 /$ j.1467-8624.2011.01637.x 
vary primarily in terms of the social motivations, attitudes and behaviors that characterize them, and the events which precipitate changes from one phase to the next. Of particular relevance to the present discussion are the in-group preference and out-group prejudice phases.

Briefly, central to the in-group preference phase is children's focus on, and concern for, their continuing membership of their in-group, as well as the positive distinctiveness of the in-group, in comparison with other groups. On this basis, SIDT predicts that children in the in-group preference phase will always like their own group and prefer it to other groups, who will be liked less and seen as possessing less positive qualities, compared with the in-group. Given the importance of peer group membership to children, SIDT also proposes that children are likely to be motivated to maintain, if not enhance, the status or standing of their group, and to take on the culture of their group (i.e., attitudes, beliefs, and behaviors) as their own.

Further, SIDT proposes that some (but not necessarily, all) children's attitudes toward the members of an out-group may change from mere in-group preference to out-group prejudice (i.e., feel dislike or hatred toward an out-group, rather than merely greater preference for the in-group), under particular circumstances. These include whether the children highly identify with their in-group, and/or out-group prejudice is a norm or expectation held by the members of the child's social group, and/or there is a belief among the in-group members that their group is threatened in some way by members of the out-group.

In sum, according to this approach, whether or not particular children, or groups of children, display prejudice, is dependent upon their unique social situation, rather than their particular age or specific cognitive abilities (cf, Aboud, 1988; Bigler \& Liben, 2007). Importantly, SIDT recognizes that children's social knowledge or social acumen (i.e., their understanding of how friendships and groups work, and how to get along with individuals and groups) increases as they grow older in response to their ever-expanding social interaction experiences, and that this knowledge influences their subsequent interpretations of social situations and the

3 nature of their responses (Nesdale, 2004a,b, 2007). In particular, SIDT holds that children develop an increasing tendency to regulate the expression of particular attitudes and behavior in accordance with who is present in a particular situation, and what attitudes and behavior are considered acceptable or might achieve a particular desired outcome.

\section{Research on Children's Intergroup Attitudes}

Consistent with SIDT's propositions, research has revealed that, certainly by school age, children seek to be members of social groups, and that they tend to like, and see themselves as similar to, in-group compared with out-group members (Bigler, 1995; Bigler, Jones, \& Lobliner, 1997; Nesdale, Durkin, Maass, \& Griffiths, 2004, 2005). Findings also reveal that children derive at least some of their self-concept and sense of self-worth from their group memberships (Bennett \& Sani, 2008; Verkuyten, 2001, 2007), and that they prefer to be members of higher rather than lower status groups (Nesdale \& Flesser, 2001). There is also evidence that children reveal a strong bias toward their in-group when they are required to make choices, indicate preferences, or allocate rewards between the in-group and an out-group, and that they display in-group positivity versus outgroup negativity in their trait attributions (see Nesdale, 2007).

While the preceding findings confirm SIDT's predictions concerning children in the in-group preference phase, there is also supportive evidence relating to SIDT's claims concerning the effects of in-group identification and out-group threat in turning children's in-group preference into out-group prejudice (Nesdale, Maass, Durkin, \& Griffiths, 2005; Nesdale, Durkin, et al., 2005). The third critical factor specified by SIDT that causes intergroup prejudice in young children relates to the social group's norms or expectations concerning appropriate attitudes and behaviors.

\section{Social Group Norms and Intergroup Prejudice}

Consistent with the focus of the present study, and with SIDT, research has shown that in-group preference turned to out-group dislike when the in-group had a norm of out-group unfriendliness and exclusion versus friendliness and inclusion (e.g., Nesdale, Maass, et al., 2005; Nesdale, Kokkoris, \& Dalton, 2010; Study 1), and that an exclusion group norm negated children's tendencies toward empathy for the members of ethnic minority outgroups (Nesdale, Griffiths, Durkin, \& Maass, 2005).

Moreover, whereas research has revealed that most children in middle childhood consider it is unfair and wrong for groups to exclude (potential) members based on gender and race (Killen \& Stangor, 2001), other research has shown that children who are group members do not necessarily think less of their group if it has a norm of exclusion versus inclusion toward nonmembers and out-groups 
(Nesdale, Maass, Kiesner, Durkin, \& Griffiths, 2008), and still express attitudes that are consistent with their group norm (e.g., Nesdale, et al., 2010; Study 1). Similarly, Abrams, Rutland, Cameron, and Ferrell (2007) reported that children's judgments of others' exclusion behavior was contingent on whether the individual was considered to be supporting or rejecting an in-group norm.

However, whereas the preceding evidence confirms the influence of group norms on children, there are also findings indicating that the group norm effect might be blunted or inhibited in particular social situations, as children increase in age. Such situations might include, for example, those in which the in-group endorses negative attitudes and behaviors, such as out-group exclusion or bullying, and the child's responses are being reported to, or observed by, adults. Consistent with this is research indicating that children learn that intergroup prejudice and discrimination are considered to be unacceptable and inappropriate by parents and teachers (Brown \& Bigler, 2004; Greenwald \& Banaji, 1995; Rutland, Cameron, Milne, \& McGeorge, 2005) and begin to engage in self-presentational behavior that puts them in the best possible light to significant others, from approximately 7 years of age (Aloise-Young, 1993; Banerjee, 2002; Banerjee \& Yuill, 1999; Bennett \& Yeeles, 1990).

More directly, several studies have reported that, despite their in-group's endorsement of out-group exclusion and rejection, the negativity of children's intergroup attitudes (Nesdale, Maass, et al., 2005; Nesdale et al., 2010; Study 2), and the likelihood of children engaging in bullying and aggression (Nesdale et al., 2008), tended to decrease as they increased in age, in a situation in which their responses were being reported to adults.

One aim of the present study was to shed more light on the foregoing issue by varying the social acceptability of the in-group's norm and examining its influence on the participants' intra and intergroup attitudes. Participants were assigned to a social group which had a norm of inclusion and friendliness toward others, or a group norm of exclusion and unfriendliness toward others, or a group norm of exclusion-plus-relational aggression toward others (i.e., an expectation that group members would exclude others and would say and do mean things toward other children).

Drawing upon SIDT, it was expected that the participants' attitudes toward the out-group would be more negative when the in-group had a norm of exclusion, or exclusion-plus-relational aggression, compared with a norm of inclusion and friendli- ness. However, consistent with the earlier discussion, it was also anticipated that the participants' more negative attitudes toward the out-group arising from the in-group's exclusion norm would tend to decrease as the participants increased in age and the norm became more negative (i.e., exclusionplus-relational aggression norm vs. exclusion norm), because of the participants' concerns about how they might be viewed by adults.

\section{Moderating Children's Group Attitudes}

Several approaches to modifying children's negative intergroup attitudes have been assessed, including facilitating positive interethnic contact (Allport, 1954; Pettigrew, 1998), enhancing the utilization of particular cognitive processes (e.g., multiple classification) to counteract category- or group-based responding (Aboud, 1988; Bigler \& Liben, 1993, 2007), and encouraging the recategorization of group membership so as to include both in-group and out-group members (Gaertner et al., 2008). However, few attempts have been made to moderate negative intergroup attitudes when they are underpinned by a norm endorsed by a child's social group.

The second aim of the present research was to assess the impact of another, more common approach used by school authorities to moderate children's attitudes and behavior. Specifically, for many years, it has been commonplace for school authorities to specify various expectations or norms concerning the appropriate attitudes, beliefs and behaviors to be displayed by children toward each other (e.g., inclusiveness, friendliness), as well as those not to be displayed (e.g., prejudice, discrimination, bullying). However, little research attention has been given to the efficacy of this approach.

Accordingly, the present research sought to assess the impact of a school norm (inclusion and friendliness vs. no school norm) on children's intergroup attitudes. It was anticipated that children's intergroup attitudes would be more positive when they were exposed to the school norm.

The third issue of particular interest to the present research was the situation in which a norm endorsed by a child's social group happened to conflict directly with a norm endorsed by the school. In the present research, the school endorsed an expectation that children would be inclusive and friendly toward other children, whereas the norm endorsed by one of the children's groups was that children should be excluding and unfriendly toward other children. Thus, the norms concerned 
a moral issue (being accepting, friendly and inclusive toward other children) but were directly contrary to each other (one pro, the other, con), with the source being the child's social group versus the school. The critical question here was: to which would the child respond-the group norm or the school norm?

Although several outcomes of such a situation are possible, the most plausible prediction is that the relative effects of the group versus school norms might differ according to the age of the children. Consistent with SIDT, this prediction is based on the research outlined above indicating that children in middle childhood know that negative attitudes and behaviors, such as intergroup prejudice, aggression, and bullying, are considered to be unacceptable and inappropriate by teachers and parents (e.g., Brown \& Bigler, 2004; Greenwald \& Banaji, 1995; Rutland, 1999; Rutland et al., 2005) and they have a growing tendency toward displaying behavior that puts them in the best possible light, in this case, with adults (e.g., Aloise-Young, 1993; Banerjee, 2002; Banerjee \& Yuill, 1999; Bennett \& Yeeles, 1990).

On this basis, it is plausible that the intergroup attitudes of younger children in middle childhood would be influenced more by their social group norms than by those of the school. In contrast, as they increase in age, it is likely that children would be increasingly responsive to the norms of the school versus those of their social group, especially when in the presence of adults, such as teachers and parents. Thus, according to this prediction, it is likely that younger children would favor their ingroup and that their out-group attitudes would reflect the positive or negative norms of their social group, rather than the norms of the school. In comparison, it is likely that older children's tendencies toward acceding to the (negative) group norm (i.e., exclusion, exclusion-plus-relational aggression) would be moderated when the school has a norm that conflicts with such attitudes and behavior.

\section{Present Study}

The study utilized a group simulation paradigm that has been used successfully in a number of studies examining the effects of children's social group membership on their intergroup prejudice (e.g., Nesdale \& Flesser, 2001; Nesdale et al., 2004; Nesdale, Maass, et al., 2005). A particular advantage of this paradigm is that it allows for the manipulation of variables relating to the in-group, the out-group, and the context, thus enabling causal inferences to be drawn, a possibility that is not afforded to correlational designs.

The study examined the effects of social group norms, and school norms, on 7- and 10-year-old children's intergroup attitudes. Participants were assigned to groups that had either a norm of inclusion, exclusion, or exclusion-plus-relational aggression, and were informed that the school had a norm of inclusion, or were given no information about a school norm. Participants subsequently responded to questions that assessed their attitudes toward the in-group and the out-group.

\section{Method}

\section{Participants}

The sample comprised 383 Anglo-Australian children (170 males and 213 females), with the younger age group (195 children; 89 males and 106 females) from grades $1-3(M=7.86, S D=0.83)$ and the older age group (188 children; 81 males and 107 females) from grades 4-6 $(M=10.85, S D=1.07)$. The children attended four primary schools serving the same lower-middle class community and participated only with parental approval, as well as with their own assent.

\section{Design}

The experiment utilized a 2 (participant age: 7 vs. 10 years) $\times 2$ (participant gender) $\times 3$ (group norm: inclusion vs. exclusion vs. exclusion + relational aggression) $\times 2$ (school norm: inclusion vs. no school norm) $\times 2$ (timing of norm presentation: group norm first vs. group norm second) $\times 2$ (target group: in-group vs. out-group) mixed factorial design, with the last factor within subjects. Participants were randomly assigned to one of the Group norm $\times$ School norm $\times$ Timing conditions, with the number of males and females in each condition approximately equal $(M$ male $=14, M$ female $=17)$.

\section{Materials}

Group photos. A set of head-and-shoulder color photos of children was used to present the members of the in-group and the out-group to the participants. Within age and gender, the photos were randomly drawn from a pool of photos that has been developed and pretested by the authors (Nesdale, Maass, et al., 2005). Photos selected were matched for expression (not smiling) and attractiveness (moderate). Each photo was $150 \mathrm{~mm} \times 110 \mathrm{~mm}$ 
and pasted onto a $200 \mathrm{~mm} \times 200 \mathrm{~mm}$ white cardboard square. A board was used to display the photos to the children in the study. In the first photo set, there were two centered photos with one empty space in between (where the participant's photo was to be added), whereas the second photo set consisted of three photos.

Social group norm manipulation. Social group norms were manipulated by having the children listen to a prerecorded message spoken by a child of the same age and gender as the child being tested. There were three different messages recorded for each age and gender combination: one of inclusion, one of exclusion, and one of exclusionplus-relational aggression.

Response booklet. A response booklet was prepared for each participant that contained brief instructions, some practice questions, filler items (so as to reduce the focus on the main measures), and the main measures. Responses to all questions were given on 5-point scales, with unipolar scales ranging from 1 (a small amount of the attribute) to 5 (a large amount of the attribute), whereas the response options on bipolar scales ranged from 1 (a negative response) to 3 (a neutral response) to 5 (a positive response). On both types of scales, each point on each scale was labeled appropriately.

\section{In-Group and Out-Group Attitudes}

In-group and out-group attitudes were measured by summing participants' responses on three separate scales relating to the members of the in-group, as well as to the members of the out-group. Participants indicated how much they liked the members of their own team (How much do you like the children in your team?), as well as the members of the other team (How much do you like the children in the other team?), on separate bipolar scales ranging from 1 (I don't like them at all) to 5 (I like them a lot). Similarly, the participants indicated how much they trusted the members of their own team (How much do you trust the other children in your team?), and the other team (How much do you trust the children in the other team?), on separate bipolar scales ranging from 1 (I don't trust them at all) to 5 (I trust them a lot). Finally, the children rated how much they would like to play with the members of their own team (How much would you like to play with the children in your team?), as well as the other team (How much would you like to play with the children in the other team?), on separate bipolar scales ranging from 1 (I wouldn't like to play with them at all) to 5 (I would like to play with them a lot). Thus, each participant received two summed scores, one for the in-group and one for the out-group, with each score ranging from 3 to 15. The summed scales (i.e., liking, trust, play) had a Cronbach's alpha of .89 for the in-group and .89 for the out-group. These scales have been used successfully in a series of studies designed to assess children's in-group and out-group attitudes (e.g., Nesdale, Maass, Griffiths, \& Durkin, 2003; Nesdale et al., 2004; Nesdale, Maass, et al., 2005; Nesdale, Durkin, et al., 2005; Nesdale, Griffiths, et al., 2005).

\section{Procedure}

All students in grades 1-6 from the participating schools were asked by their teachers to do a drawing of themselves on a $145 \mathrm{~mm} \times 210 \mathrm{~mm}$ piece of paper. The children were told that during the next week some visitors would look at their drawings, if their parents had given permission for them to participate. One to 2 weeks later, each participant was called out of his/her class and tested individually in a distraction-free environment.

Critical to the success of the simulation group paradigm was the need for the child to feel that $\mathrm{s}$ /he was a member of a particular "team" or "group" and that s/he identified with that group. To achieve this goal, the script followed by the researcher continually emphasized the participant's membership in his/her team, the child was symbolically "fitted into" his/her team via their photograph, and the response measures always referred to the child's "team" or "group," versus the other "team" or "group." This procedure has been used successfully in a series of previous studies (e.g., Nesdale et al., 2004, Nesdale, Maass, et al., 2005; Nesdale, Durkin, et al., 2005).

Thus, at the outset, the participant was asked to pretend that $\mathrm{s} /$ he was going to participate in a team in an intergroup drawing competition that would involve children from other schools in the area. Accordingly, participants were asked to pretend that all the children's drawings had been judged by an artist and that the children were being put into teams of similar drawing ability. They were then asked if it was okay to have their instant photo taken, and all participants agreed.

Since intergroup prejudice is typically expressed by individuals with higher status toward those with lower status, the children were then asked to pretend that their drawing had been viewed by judges who had decided that their excellent performance had qualified them to be a member of a team of excellent drawers, thus enhancing the 
perceived social status of their group. They were then shown photos of two other children of the same age and sex (photo set 1) and were told that this was their team. They were asked to put their photo in the empty slot between the photos of their team members and to have a good look at their team because they would later be asked some questions about them. In order to enhance in-group identification, the participants were then told that their team members had asked them to pick their team's color, which the researcher then wrote on a sticky note and attached to their team's photos. The researcher next put a star next to their team because they were "excellent drawers," in order to increase the perception of in-group status.

The participants were then shown photos of the same age and sex children in the other team (photo set 2), and told that they would be competing against them in the drawing competition. They were told that the other team's drawings had been just ok, and were not as good as your excellent team (increasing the status disparity between the groups).

Measured at this point, previous research has shown that participants reveal significant liking and trust for their team, and have a desire to play with them. They also see themselves as similar to their other group members. In addition, they express significantly more liking, trust, similarity, and desire to play with, their in-group versus the out-group members (Nesdale \& Flesser, 2001). Finally, they consider their group to have higher status than the out-group, as intended (e.g., Nesdale et al., 2004).

In the present study, the experimenter then carried out the social group norm manipulation, in accordance with the participant's randomly assigned condition. Again, critical to the success of this manipulation was the need for the participant to believe that the message came from the team, and hence was a team norm. Thus, each participant was first told that his/her group had recorded a "secret message" for only the participant to hear. To emphasize this point, before and after the message, the researcher told the participant that, this is for your ears only; I am not allowed to know what the message is, so you must keep your team's secret message to yourself. The participant was then asked to put on head phones in order to listen to the secret message. This device was employed so as to differentiate the presentation of the norms of the social group versus the school, otherwise the researcher would have been left verbally presenting the norms of both the social group and the school, in sequence.

In each social group norm condition, the participant first heard several same age and sex voices welcome $\mathrm{him} / \mathrm{her}$ to the team (e.g., Hullo, we're really happy you are going to be in our team). The participant then heard one "team member" speak on behalf of the team. Thus, in the inclusion group norm condition, the participant heard a "team member" explain that if the participant wanted to be a member of the team, they must like and include all the members of all other teams. In contrast, in the exclusion group norm condition, the participant heard a "team member" explain that if the participant wanted to be a member of the team, they must not like or be friendly to any members of the other teams. Finally, in the exclusion-plus-relational aggression group norm condition, the participant heard a "team member" explain that if the participant wanted to be a member of the team, they must not like or be friendly to any members of the other teams and that they must be prepared to say mean things about kids in the other teams and to have them left out of games and activities. Thus, in each condition, the requirement specified was one required by the team, in order to retain membership of the team.

To carry out the school norm manipulation, participants in the school norm condition were told by the researcher that, your principal and teacher have said to me that this school likes all the children to like kids in other groups and to be friendly toward them. Conversely, in the no school norm condition, no mention was made of how the school wanted the children to feel toward other children.

In order to control for any order effects linked to the enactment of the social group norm manipulations and the school norm manipulations, the timing of the group norm and school norm messages was systematically varied. Thus, half the children heard the social group norm manipulation before the school norm manipulation; whereas the remaining half of the children heard the social group norm manipulation after the school norm manipulation.

After completing the experimental manipulations, the participants were directed to their response booklet. To insure that each child was comfortable with using the unipolar and bipolar scales, they first completed some practice questions, under the direction of the experimenter. The children were reassured that, unlike schoolwork, there are no right or wrong answers, and that, we are just interested in what you think is the best answer for you. The participants then completed the questions with the 
researcher reading out the questions to insure that all participants heard the same question and response alternatives.

When the session was completed, the participant was debriefed and given the opportunity to ask any questions. In order to check the effectiveness of the group norm manipulations, the participants in the inclusion group norm condition and the exclusion group norm condition were asked whether their team likes kids in other teams. The results indicated that $96.06 \%$ of participants in the inclusion condition responded affirmatively to the first question, whereas $93.07 \%$ of participants in the exclusion condition responded negatively to this question. In addition, children in the exclusionplus-relational aggression norm condition were asked whether their team likes to say mean things about the kids in the other teams. The results showed that $87.5 \%$ of participants in this condition responded affirmatively to the question. To check the effectiveness of the school norm manipulation, participants were asked whether their school likes children to like the children in other teams. The results indicated that $95.21 \%$ of children in the school norm condition responded affirmatively, whereas $85.2 \%$ of participants in the no school norm condition responded in the negative. Finally, in an attempt to control for possible contamination between participants, each child was asked to keep the details of the pretend game secret from the other children so that it would be a new game for them. All the participants agreed to do so. The participant was then given his/her own photo, thanked for participating in the pretend game, and returned to their classroom.

\section{Results}

Participants' summed attitude ratings for the ingroup and out-group were first examined for any effects due to participant gender and timing of the norm presentation. In the absence of such effects, participants' in-group and out-group attitudes were analyzed in a 2 (participant age: 7 vs. 10 ) $\times 3$ (group norm: inclusion vs. exclusion vs. exclusion + relational aggression) $\times 2$ (school norm: inclusion vs. no school norm) $\times 2$ (target group: in-group vs. out-group) analysis of variance (ANOVA), with the last factor within subjects. This analysis revealed several significant findings relating to the influence of the social group norms and school norms on the participants' in-group and out-group attitudes.
Effects of Social Group Norms on Participants' Attitudes

The analysis revealed a significant social group norm main effect, $F(2,371)=49.08, p<.001$, partial $\eta^{2}=.21$. Comparison of the cell means indicated that the participants had more negative attitudes toward the groups when the in-group had a norm of exclusion $(M=8.57, S D=3.88)$, or a norm of exclusion-plus-aggression $(M=8.87, S D=4.17)$, compared with an inclusion group norm $(M=11.22, S D=2.91)$. The means of the two exclusion group norm conditions were not significantly different from each other.

The preceding effect was qualified by a significant Participant age $\times$ Social group norm $\times$ Target group interaction effect, $F(2,371)=7.03, p<.001$, partial $\eta^{2}=.04$. The means for this interaction are displayed in Figure 1. Comparisons of the cell means indicated that, at 7-years of age, participants were more negative toward the out-group than the in-group, regardless of the in-group's norm. At the same time, however, their attitudes were affected by the in-group's norms. Thus, consistent with the in-group norms, the participants were significantly more negative toward the out-group when the in-group had a norm of exclusion $(M=6.77$, $S D=3.79)$, or a norm of exclusion-plus-relational aggression $(M=7.61, S D=4.35)$, than when the ingroup had a norm of inclusion $(M=10.14$, $S D=3.53$ ).

The participants' attitudes toward the in-group were also affected by the in-group's norm. Thus, although the participants were more positive toward the in-group than the out-group, their in-group attitudes were significantly more negative when the in-group had a norm of exclusion $(M=11.55, S D=3.30)$, or a norm of exclusion-plusrelational aggression $(M=11.11, S D=3.91)$, than when the in-group had a norm of inclusion $(M=12.98, S D=2.42)$.

Consistent with the younger children, the outgroup attitudes of the 10-year-old participants were also determined by the norms of their social group. Thus, the participants' attitudes toward the outgroup were significantly more negative when the in-group had a norm of exclusion $(M=8.48$, $S D=3.63)$, or a norm of exclusion-plus-relational aggression $(M=8.66, S D=3.49)$, than when the in-group had a norm of inclusion $(M=10.22$, $S D=2.87)$. However, in contrast to the 7-year-olds, the older children's attitudes toward the in-group were substantially more negative when the in-group had a norm of exclusion $(M=7.45$, 
7-Year Old Children

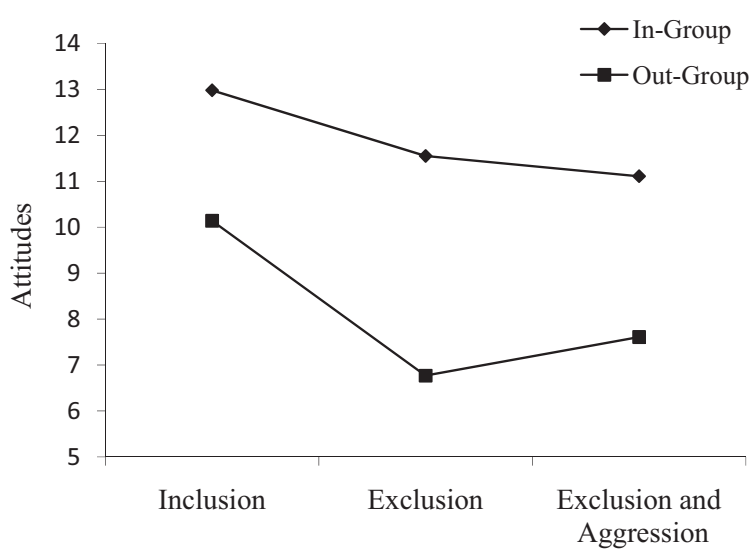

Social Group Norms

10-Year Old Children

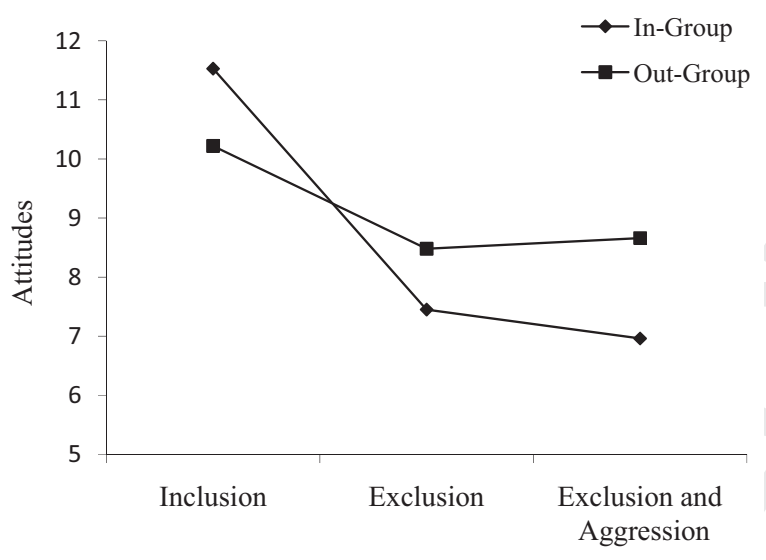

Social Group Norms

Figure 1. Means for the Participant age $\times$ Social group norm $\times$ Target group interaction effect on intergroup attitudes.

$S D=3.52)$, or a norm of exclusion-plus-relational aggression $(M=6.96, S D=3.81)$, compared with a norm of inclusion $(M=11.53, S D=2.64)$. Indeed, whereas the participants were significantly more negative toward the out-group $(M=10.22, S D=$ 2.87) than the in-group $(M=11.53, S D=2.64)$ when the in-group had a norm of inclusion, there was no difference in their attitudes toward the outgroup $(M=8.48, S D=3.63)$ and the in-group $(M=7.45, S D=3.52)$ when the in-group had a norm of exclusion, but the participants' attitudes toward the out-group $(M=8.66, S D=3.49)$ versus the in-group $(M=6.96, S D=3.81)$ were significantly more positive when the in-group had a norm of exclusion-plus- relational aggression.

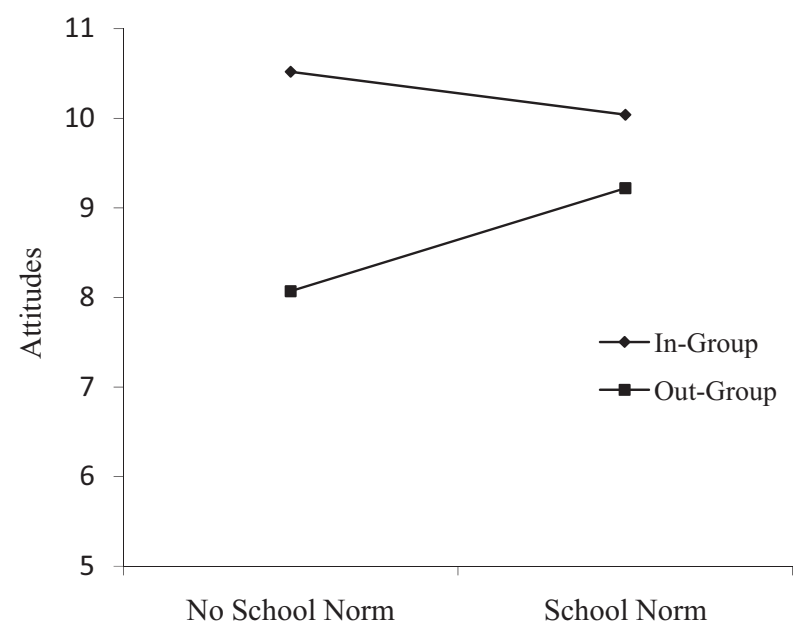

Figure 2. Means and standard deviations for School norm $\times$ Target group interaction effect on intergroup attitudes.

Effects of School Norms on the Participants' Attitudes

The analysis yielded a significant School norm $\times$ Target group interaction effect, $F(1,371)=$ 10.13, $p<.01$, partial $\eta^{2}=.03$. As indicated in Figure 1, comparison of the cell means revealed that the participants' attitudes toward the outgroup members were significantly more positive when there was a school norm $M=9.22, S D=3.85$ ) than when there was no school norm $(M=8.07$, $S D=3.74)$. In contrast, the participants' attitudes toward the in-group were unaffected by whether there was a school norm $(M=10.04, S D=4.19)$ or no school norm $(M=10.52, S D=3.76)$.

The Age $\times$ Social group norms $\times$ School norms $\times$ Target group interaction effect on the participants' intergroup attitudes was not significant, $F(2$, $371)=0.50, p>.61$.

\section{Effects of Participant Age}

The analysis also revealed significant main effects for participant age, $F(1,371)=20.75, p<.001$, partial $\eta^{2}=.05$, and for target group, $F(1,371)=$ 41.24, $p<.001$, partial $\eta^{2}=.10$, both of which were qualified by a significant Participant age $\times$ Target group interaction effect, $F(1,371)=69.35, p<.001$, partial $\eta^{2}=.15$. Comparison of the cell means using Duncan's Multiple Range Test indicated that the 7-year-old participants had significantly more negative attitudes toward the out-group $(M=8.17$, $S D=4.14)$ than the in-group $(M=11.88, S D=$ 3.35), whereas there was no significant difference in the positivity of the 10-year-old participants 
Table 1

Means and standard deviations for Participant age $\times$ Social group norm $\times$ Target group interaction effect on intergroup attitudes

\begin{tabular}{|c|c|c|c|c|c|c|}
\hline \multirow{2}{*}{$\begin{array}{l}\text { Norm: } \\
\text { Group: }\end{array}$} & \multicolumn{2}{|c|}{ Inclusion } & \multicolumn{2}{|c|}{ Exclusion } & \multicolumn{2}{|c|}{ Exclusion-plus-aggression } \\
\hline & In-group & Out-group & In-group & Out-group & In-group & Out-group \\
\hline 7 years & $12.98_{\mathrm{e}}(2.42)$ & $10.14_{c}(3.53)$ & $11.55_{\mathrm{d}}(3.30)$ & $6.77_{a}(3.79)$ & $11.11_{\mathrm{cd}}(3.91)$ & $7.61_{\mathrm{ab}}(4.35)$ \\
\hline 10 years & $11.53_{\mathrm{d}}(2.64)$ & $10.22_{c}(2.87)$ & $7.45_{\mathrm{ab}}(3.52)$ & $8.48_{\mathrm{b}}(3.63)$ & $6.96_{a}(3.81)$ & $8.66_{\mathrm{b}}(3.49)$ \\
\hline
\end{tabular}

Note. Means sharing different subscripts are significantly different, Duncan's Multiple Range Test, $p<.05$.

attitudes toward the in-group $(M=8.63, S D=3.92)$ and the out-group $(M=9.11, S D=3.42)$.

\section{Discussion}

Research shows that the norms or expectations of children's social groups can exert a powerful influence on the intergroup attitudes and behaviors displayed by group members toward other children, although there is some evidence that this effect might diminish with age, especially when the group norm calls for negative intergroup attitudes and behavior (Nesdale, Maass, et al., 2005, 2010, Study 2). One aim of the present research was to test this speculation by varying the positivity of a group norm and examining its effects on children's intra and intergroup attitudes.

The second aim of the study was to examine the impact of school norms or rules on children's attitudes. In addition, the research assessed the situation in which a school norm concerning children's attitudes and behaviors (e.g., liking and friendliness toward others) actually conflicts with a norm endorsed by the child's social group (e.g., dislike, unfriendliness toward others). The question here was whether the child's intergroup attitudes would be influenced by the group norm, the school norm, or both, and whether the particular effect might be influenced by the age of the child.

\section{Social Group Norms and Children's Intergroup Attitudes}

Consistent with SIDT, the results revealed a significant Participant age $\times$ Social group norm $\times$ Target group interaction effect (see Table 1). This finding indicated that the participants' out-group attitudes were determined by their in-group's norms. Thus, at both 7 and 10-years of age, the participants liked the out-group less when the in-group had a norm of exclusion or a norm of exclusion-plus-relational aggression, compared with a norm of inclusion.
However, the in-group norms also affected the participants' attitudes toward their in-group, and in different ways at the different ages. Thus, at 7-years, the participants always liked their in-group more than the out-group, although their liking for the in-group decreased when the in-group had a norm of exclusion, or a norm of exclusion-plusrelational aggression, compared with when the in-group had a norm of inclusion.

In contrast, at 10-years of age, there was a substantial reduction in the participants' liking for the in-group when the in-group had a norm of exclusion, or a norm of exclusion-plus-relational aggression, compared with when the in-group had a norm of inclusion. Indeed, whereas the participants liked the out-group less than the in-group when the in-group had a norm of inclusion, there was no difference in liking for the in-group and out-group when the in-group had a norm of exclusion, and the participants actually liked the out-group more than the in-group when the latter had a norm of exclusion-plus-relational aggression.

There are several noteworthy aspects of this finding. First, despite never having met any other in-group members, and the membership of their "social group" being very brief, the children's intergroup attitudes still revealed the influence of their group's norms. That is, consistent with SIDT, the participants at both ages evidenced significantly less liking for the out-group when the in-group had an exclusion group norm (i.e., exclusion, or exclusion-plus-relational aggression), versus an inclusion group norm.

Second, whereas previous research has revealed the influence of classroom norms on children's attitudes and behavior (Henry, 2001; Henry et al., 2000; Salmivalli \& Voeten, 2004; Stormshak, Bierman, Bruschi, Dodge, \& Coie, 1999), it is noteworthy that in the present study the norm was held by only a small group. That is, while a norm that is held by a whole class confers considerable authority and influence on that norm, the children in the present study showed a similar degree of 
responsiveness to their social group, despite its limited size. Yet again, this emphasizes the importance of group membership to young children, extending to a willingness to adopt their social group's norms.

Third, although the findings clearly evidenced the impact of both the exclusion group norms (i.e., exclusion, exclusion-plus-relational aggression) on the children's attitudes toward the out-group members, the findings also revealed that the children liked their in-group less when it had an exclusion group norm. However, as predicted by SIDT, there was an important age difference. At 7-years of age, the children continued to like their in-group more than the out-group even when the in-group had an exclusion norm or an exclusion-plus-relational aggression norm, although they liked the in-group less than when the in-group had an inclusion norm.

In contrast, at 10-years of age, when the in-group had an exclusion group norm, the children liked the out-group as much as the in-group. But, when the in-group had an exclusion-plus-relational aggression group norm, the older children actually liked the out-group more than the in-group. From another perspective, whereas the children's outgroup attitudes accorded with the in-group's norms, as the children increased in age, an ingroup norm of exclusion caused them to like the in-group less, whereas they tended to like the outgroup more. These findings are consistent with the results of earlier studies which reported that, despite their in-group's endorsement of out-group exclusion and rejection, the negativity of children's intergroup attitudes (Nesdale, Maass, et al., 2005, 2010, Study 2), and the likelihood of children engaging in bullying and aggression (Nesdale et al., 2008), tended to decrease as they increased in age.

Fourth, the group norm of exclusion-plus-relational aggression did not produce more negative out-group attitudes than did the exclusion group norm condition despite the fact that, in the former condition, the children were told to "say mean things about them" and "leave them out of games and activities." There are at least two possible explanations for this outcome. One possibility is that the exclusion group norm condition was simply interpreted by the children to encompass the same range of possible behaviors as were made explicit in the exclusion-plus-relational aggression group norm condition. However, a second possibility is that the children might have reacted against being assigned to a group with such a group norm (i.e., the exclusion-plus-relational aggression condition), at least to the extent of not expressing more negative out-group attitudes beyond those displayed by children in the exclusion group norm condition.

Although the present findings do not allow a resolution of this issue, there is some evidence consistent with the latter interpretation. Specifically, although the participants in the exclusion-plus-relational aggression condition were no more negative toward the out-group than were participants in the exclusion group norm condition, the former participants actually liked their in-group significantly less than did the latter participants.

In sum, these findings give further emphasis to the considerable influence exerted by the social group on children during middle childhood, with both the younger and older children being prepared to be influenced by an exclusion norm endorsed by their in-group. However, while their out-group attitudes were still consistent with their in-group norm, they were clearly not happy about the exclusion group norm and, consequently, liked their in-group less. Indeed, the older participants actually went so far as liking the in-group less than the out-group under these circumstances, a considerably rare outcome in intergroup research (Nesdale, 2007).

That said, it is important to recognize that the participants' in-group and out-group attitudes reflected their particular circumstance (i.e., their in-group having an exclusion norm) and that the in-group and out-group attitudes displayed in this study might become more positive or negative under other circumstances. For example, it is plausible that the participants' out-group attitudes would have been more negative, at both ages, if they believed that the standing of their group was under threat from the out-group. Consistent with this, Nesdale, Maass, et al. (2005) reported that the out-group attitudes of both 7- and 9-year-old participants were most negative when the in-group had an exclusion norm and the out-group threatened the status of the in-group. Viewed together, the foregoing findings suggest that children take into account the particular features of their social circumstance in deciding how they will react.

Group Norms, School Norms, and Children's Intergroup Attitudes

The present study also addressed the issue of whether school norms impact on children's intergroup attitudes and, in particular, whether school norms that directly oppose the norms endorsed by children's social groups have the effect of extinguishing or, at least, moderating the effects of the social group norms. 
Consistent with SIDT, the findings revealed that school norms significantly influenced the children's intergroup attitudes. Specifically, a School norm $\times$ Target group interaction effect indicated that the participants' attitudes toward the out-group members were significantly more positive when there was a school norm that endorsed inclusion, than when there was not. In contrast, the participants' attitudes toward their in-group were unaffected by whether there was a school norm. However, contrary to expectations, there was no interactive effect of Age $\times$ Social group norms $\times$ School norms on the participants' intergroup attitudes.

There are several points to be made about this pattern of findings. First, the finding that school norms can exert a significant impact on young children's intergroup attitudes presumably reflects their increasing awareness of the importance of listening and responding positively to the injunctions of adults in authority, especially concerning attitudes and behaviors that are considered to be unacceptable and inappropriate (e.g., Brown \& Bigler, 2004; Greenwald \& Banaji, 1995; Rutland, 1999; Rutland et al., 2005). In addition, this finding coincides with research indicating that, during the middle childhood period, children have an increasing tendency toward engaging in self-presentational behavior that puts them in the best possible light, especially when when they are being observed by adults (e.g., Aloise-Young, 1993; Banerjee, 2002; Banerjee \& Yuill, 1999; Bennett \& Yeeles, 1990; Rutland et al., 2005).

Second, it is also noteworthy that the effect of the school norm was not interactively inluenced by the participants' age. That is, the impact of the school norm on the children's attitudes did not increase with age, as was expected. Clearly, even at 7 years of age, children are aware of the need to hear and respond affirmatively to adults' communications reinforcing some behaviors, and discouraging or forbidding others.

Given that the school norm did exert a significant effect on the children's out-group attitudes, perhaps one implication is that teachers and school administrators should give special consideration to methods that can be employed to keep school norms and rules fresh and vibrant to young children. Given that recess and lunch times are the times at which most negative interpersonal and intergroup incidents occur (Rigby, 1996), presumably because supervision is lower during these times, the importance of enhancing school norm salience seems clear.
Third, while the manipulation of the school norm had a significant impact on the participants' out-group attitudes, the school norm did not interactively influence the effect of the social group's norms on children of different ages. Specifically, the school norm did not moderate, let alone extinguish, the impact of the exclusionary group norms. Instead, the group norm and school norm effects were independent of each other.

Whereas these findings lend themselves to several possible interpretations, perhaps the most plausible is that the need to respond affirmatively to both group and school norms in the present situation would be highly salient to young children, hence their responses to these norms were simply compartmentalized from each other. That is, based on their increasing social knowledge, the children would likely be aware that it would be wise to try to respond positively to both sources of influence so as not to run afoul of either source. On the one hand, not to endorse the in-group's norms would be to invite disapproval, perhaps even rejection, by the social group. On the other hand, not to endorse the school's norms would also invite trouble from the school authorities, perhaps even implicating the child's parents.

Although the foregoing explanation places emphasis on children's developing social knowledge or social acumen (Nesdale, 2004a,b, 2007), it is worth noting that other researchers are also showing interest in this emphassi. For example, Abrams and colleagues (Abrams, Rutland, Pelletier, \& Ferrell, 2009), in a not dissimilar vein, have focused on children's developing social-cognitions, such as group nous (i.e., their "know-how about group processes such as loyalty, conformity pressure, and groups showing in-group biases," p. 226) and their theory of social mind (TOSM; i.e., their "understanding of social perspectives and emotions that arise in social relationships" p. 227), as important influences on children's responses in such situations. Moreover, research has yielded some support for their proposals (e.g., Abrams et al., 2009). However, considerably more research is needed in order to clarify the social cognitive basis of children's attitudes and behaviors in intergroup situations.

It also needs to be recognized that while the children were aware of, hence responded affirmatively to, the school norm, it might not have been sufficiently salient, or at least as salient to them as the norm of their social group. Consequently, while the school norm had a significant effect, its actual manipulation might not have been sufficiently 
powerful to moderate or extinguish the group norm effect.

Although it is not possible to resolve this issue based on the present findings, consistent with the latter suggestion is the possibility that the group versus school norms had differential salience as a result of the difference in methods of manipulating these norms. Thus, as with so much that is imparted at school, the school norm was yet another injunction delivered by an adult. In contrast, the group's norm was delivered via a "secret message" from the group members, perhaps giving it something of a mysterious and conspiratorial, hence exciting, connotation.

We were aware of this possibility when the study was being designed but felt that both forms of delivery were actually quite representative of social reality. That is, teachers and other adults probably deliver endless public injunctions about attitudes and behavior that they wish children to display. In contrast, the norms that are held by groups belong to the group members and hence are not widely broadcast (they are "secrets"). Accordingly, because of the unique features of the two message forms, it might have been the case that the group norm was more salient in the circumstance hence out-weighed some of the effects of the school norm. That said, the validity of this speculation will need to be tested in future research.

\section{Conclusions}

The present study examined the separate and interactive effects of social group norms and school norms on 7- and 10-year-old children's in-group and out-group attitudes. Consistent with SIDT, the findings indicated that the social group norms instigated out-group attitudes consistent with the social group norms. In addition, however, the findings indicated that, whereas the participants were prepared to conform to their group's norms, they liked their in-group less if the in-group norm endorsed exclusionary behavior toward out-group members, especially among the older participants. Finally, although the manipulation of school norms did not moderate or extinguish contrary group norms as was expected, the school norms did instigate an increase in the positivity of the participants' attitudes toward out-group members, consistent with the school norm. The results emphasize the need for more research designed to enhance the salience and impact of school norms, possibly as a means of counteracting the possible influences of children's social groups.

\section{References}

Aboud, F. E. (1988). Prejudice and children. Cambridge MA: Basil Blackwell.

Abrams, D., \& Rutland, A. (2008). The development of subjective group dynamics. In S. Levy \& M. Killen (Eds.), Intergroup attitudes and relations in childhood through adulthood (pp. 32-46). Oxford: Oxford University Press.

Abrams, D., Rutland, A., \& Cameron, L. (2003). The development of subjective group dynamics: Children's judgments of normative and deviant ingroup and outgroup individuals. Child Development, 74, 18401856.

Abrams, D., Rutland, A., Cameron, L., \& Ferrell, J. M. (2007). Older but wilier: In-group accountability and the development of subjective group dynamics. Developmental Psychology, 43, 134-148.

Abrams, D., Rutland, A., Cameron, L., \& Marques, J. M. (2003). The development of subjective group dynamics: When ingroup bias gets specific. British Journal of Developmental Psychology, 21, 155-176.

Abrams, D., Rutland, A., Pelletier, J., \& Ferrell, J. M. (2009). Children's group nous: Understanding and applying peer exclusion within and between groups. Child Development, 80, 224-243.

Allport, G. W. (1954). The nature of prejudice. Cambridge, MA: Addison-Wesley.

Aloise-Young, P. A. (1993). The development of self-presentation: Self-promotion in 6- to 10-year-old children. Social Cognition, 11, 201-222.

Banerjee, R. (2002). Audience effects on self-presentation in childhood. Social Development, 11, 487-507.

Banerjee, R., \& Yuill, N. (1999). Children's explanations for self-presentational behaviour. European Journal of Social Psychology, 29, 105-111.

Baumeister, R. F., \& Leary, M. R. (1995). The need to belong: Desire for interpersonal attachment as a fundamental human motivation. Psychological Bulletin, 117, 497-529.

Bennett, M., \& Sani, F. (2008). Children's subjective identification with social groups: A group reference effect approach. British Journal of Developmental Psychology, 26, 381-387.

Bennett, M., \& Yeeles, C. (1990). Children's understanding of self-presentational strategies of ingratiation and self-promotion. European Journal of Social Psychology, 20, 455-461.

Bigler, R. S. (1995). The role of classification skill in moderating environmental influences on children's gender stereotyping: A study of the functional use of gender in the classroom. Child Development, 66, 1072-1087.

Bigler, R. S., Jones, L. C., \& Lobliner, D. B. (1997). Categorization and the formation of intergroup attitudes in children. Child Development, 68, 530-543.

Bigler, R. S., \& Liben, L. S. (1993). A cognitive-developmental approach to racial stereotyping and reconstructive memory in Euro-American children. Child Development, 64, 1507-1518. 
Bigler, R. S., \& Liben, L. S. (2007). Developmental intergroup theory: Explaining and reducing children's social stereotyping and prejudice. Current Directions in Psychological Science, 16, 162-166.

Brown, R. (1995). Prejudice. Oxford, UK: Blackwell.

Brown, C. S., \& Bigler, R. S. (2004). Children's perceptions of gender discrimination. Developmental Psychology, 40, 714-726.

Gaertner, S. L., Dovidio, J. F., Guerra, R., Rebelo, M., Monteiro, M. B., Riek, B. M., et al. (2008). The common in-group identity model. In S. R. Levy \& M. Killen (Eds.), Intergroup attitudes and relations in childhood and through adulthood (pp. 204-219). Oxford, UK: Oxford University press.

Greenwald, A. D., \& Banaji, M. R. (1995). Implicit social cognition: Attitudes, self-esteem, and stereotypes. Psychological Review, 102, 4-27.

Henry, D. (2001). Classroom context and the development of aggression: The role of normative processes. In F. Columbus (Ed.), Advances in psychology research (Vol. 6, pp. 193-227). Hauppage, NY: Nova Science Publishers.

Henry, D., Guerra, N., Huesmann, R., Tolan, P., VanAcker, R., \& Eron, L. (2000). Normative influences on aggression in urban elementary school classrooms. American Journal of Community Psychology, 28, 59-81.

Killen, M., \& Stangor, C. (2001). Children's social reasoning about inclusion and exclusion in gender and race peer group contexts. Child Development, 72, 174186.

Nesdale, D. (2001). Development of prejudice in children. In M. Augoustinos \& K. Reynolds (Eds.), Understanding prejudice, racism, and social conflict (pp. ????-???). Lon-

6 don: Sage.

Nesdale, D. (2004a). Social identity processes and children's ethnic prejudice. In M. Bennett \& F. Sani (Eds.), The development of the social self (pp. 219-246). East Sussex: Psychology Press.

Nesdale, D. (2004b). Social acumen and ethnic prejudice in children. Paper presented at Nag's Head Conference on Children and Race: Development, Cognitions, Affect, and Stereotypes, Boca Raton, FL.

Nesdale, D. (2007). The development of ethnic prejudice in early childhood: Theories and research. In O. Saracho \& B. Spodek (Eds.), Contemporary perspectives on social learning in early childhood education (pp. 213-240). Charlotte, NC: Information Age Publishing.

Nesdale, D., Durkin, K., Maass, A., \& Griffiths, J. (2004). Group status, outgroup ethnicity, and children's ethnic attitudes. Journal of Applied Developmental Psychology, 25, 237-251.

Nesdale, D., Durkin, K., Maass, A., \& Griffiths, J. (2005). Threat, group identification, and children's ethnic prejudice. Social Development, 14, 189-205.
Nesdale, D., \& Flesser, D. (2001). Social identity and the development of children's group attitudes. Child Development, 72, 506-517.

Nesdale, D., Griffiths, J., Durkin, K., \& Maass, A. (2005). Empathy, group norms and children's ethnic attitudes. Journal of Applied Developmental Psychology, 26, 623-637.

Nesdale, D., Kokkoris, L., \& Dalton, D. (2010). Children's social groups and intergroup prejudice: Assessing the influence and inhibition of social group norms. Queensland: Griffith University.

Nesdale, D., Maass, A., Durkin, K., \& Griffiths, J. (2005). Group norms, threat, and children's racial prejudice. Child Development, 76, 652-663.

Nesdale, D., Maass, A., Griffiths, J., \& Durkin, K. (2003). Effects of ingroup and outgroup ethnicity on children's attitudes towards members of the ingroup and outgroup. British Journal of Developmental Psychology, 21, 177-192.

Nesdale, D., Maass, A., Kiesner, J., Durkin, K., \& Griffiths, J. (2008). Effects of group norms on children's intentions to bully. Social Development, 17, 889-907.

Pettigrew, T. F. (1998). Intergroup contact theory. Annual Review of Psychology, 49, 65-85.

Rigby, K. (1996). Bullying in Australian schools - And what to do about it. Melbourne, Vic: Australian Council for Educational Research.

Rubin, K., Bukowski, W., \& Parker, J. G. (1998). Peer interactions, relationships and groups. In W. Daemon (Series Ed.). \& N. Eisenberg (Vol. Ed.). Handbook of child psychology: Vol 3, social emotional and personality development (5th ed., pp. 619-700). New York, NY: Wiley.

Rutland, A. (1999). The development of national prejudice in in-group favoritism and self-stereotypes in British children. British Journal of Social Psychology, 38, 55-70.

Rutland, A., Cameron, L., Milne, A., \& McGeorge, P. (2005). Social norms and self-presentation: Children's implicit and explicit intergroup attitudes. Child Development, 76, 451-466.

Salmivalli, C., \& Voeten, M. (2004). Connections between attitudes, group norms, and behavior in bullying situations. International Journal of Behavioral Development, 28, 246-258.

Stormshak, E. A., Bierman, K. L., Bruschi, C., Dodge, K. A., \& Coie, J. D. (1999). The relation between behavior problems and peer preference in different classroom contexts. Child Development, 70, 169-182.

Verkuyten, M. (2001). National identification and intergroup evaluation in Dutch children. British Journal of Developmental Psychology, 19, 559-571.

Verkuyten, M. (2007). Ethnic in-group favoritism among minority and majority groups: Testing the self-esteem hypothesis among pre-adolescents. Journal of Applied Social Psychology, 37, 486-500. 


\section{Author Query Form}

\section{Journal: $\quad$ CDEV}

\section{Article: $\quad 1637$}

Dear Author,

During the copy-editing of your paper, the following queries arose. Please respond to these by marking up your proofs with the necessary changes/additions. Please write your answers on the query sheet if there is insufficient space on the page proofs. Please write clearly and follow the conventions shown on the attached corrections sheet. If returning the proof by fax do not write too close to the paper's edge. Please remember that illegible mark-ups may delay publication.

Many thanks for your assistance.

\begin{tabular}{|c|c|c|}
\hline Query reference & Query & Remarks \\
\hline 1 & $\begin{array}{l}\text { AUTHOR: A running head short title was not supplied; please check } \\
\text { if this one is suitable and, if not, please supply a short title that can } \\
\text { be used instead. }\end{array}$ & \\
\hline 2 & $\begin{array}{l}\text { AUTHOR: Please provide postal codes to the address for correspon- } \\
\text { dence. }\end{array}$ & \\
\hline 3 & $\begin{array}{l}\text { AUTHOR: Nesdale, 2004, has been changed to Nesdale, 2004a, 2004b } \\
\text { so that this citation matches the Reference List. Please confirm that } \\
\text { this is correct. }\end{array}$ & \\
\hline 4 & $\begin{array}{l}\text { AUTHOR: Abrams, Rutland, Cameron, et al. (2003) has not been cited } \\
\text { in the text. Please indicate where it should be cited; or delete from } \\
\text { the Reference List. }\end{array}$ & \\
\hline 5 & $\begin{array}{l}\text { AUTHOR: Abrams, Rutland, Cameron, Marques, et al. (2003) has not } \\
\text { been cited in the text. Please indicate where it should be cited; or } \\
\text { delete from the Reference List. }\end{array}$ & \\
\hline 6 & AUTHOR: Please provide the page range for reference Nesdale (2001). & \\
\hline 7 & $\begin{array}{l}\text { AUTHOR: Figure } 2 \text { has not been mentioned in the text. Please cite the } \\
\text { figure in the relevant place in the text. }\end{array}$ & \\
\hline
\end{tabular}


Required software to e-Annotate PDFs: Adobe Acrobat Professional or Adobe Reader (version 8.0 or above). (Note that this document uses screenshots from Adobe Reader $\mathrm{X}$ )

The latest version of Acrobat Reader can be downloaded for free at:http://get.adobe.com/reader/

Once you have Acrobat Reader open on your computer, click on the Comment tab at the right of the toolbar:

닙

This will open up a panel down the right side of the document. The majority of tools you will use for annotating your proof will be in the Annotations section, pictured opposite. We've picked out some of these tools below:

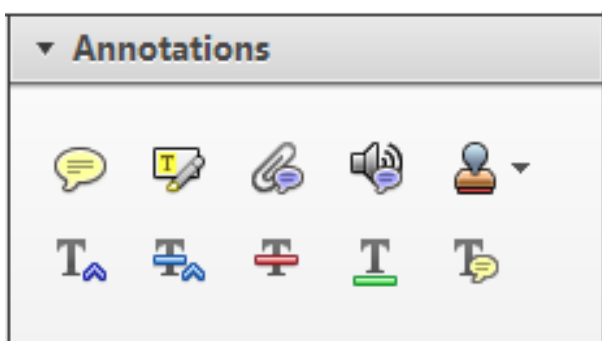

1. Replace (Ins) Tool - for replacing text.

\section{Strikes a line through text and opens up a text} box where replacement text can be entered.

\section{How to use it}

- Highlight a word or sentence.

- Click on the Replace (Ins) icon in the Annotations section.

- Type the replacement text into the blue box that appears.

Idard tramework for the analysis of $\mathrm{m}$ icy Nevertheless, it also led to exog،

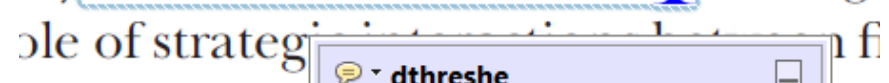
aber of comp 08/06/2011 15:58:17 $\quad$ o

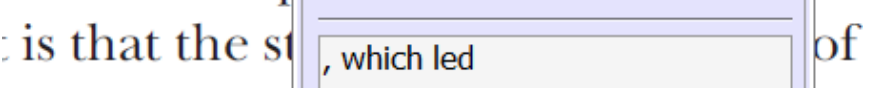
nain compo: be level, are exc nc

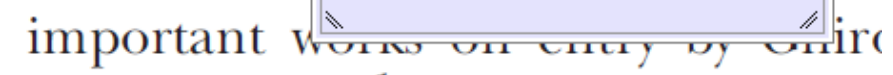
M heneforth) ${ }^{1}$ we anen the 'hlarl $\mathrm{h}$

3. Add note to text Tool - for highlighting a section to be changed to bold or italic.

Th Highlights text in yellow and opens up a text box where comments can be entered.

\section{How to use it}

- Highlight the relevant section of text.

- Click on the Add note to text icon in the Annotations section.

- Type instruction on what should be changed regarding the text into the yellow box that annears.

namic responses of mark ups ent with the VAR evidence

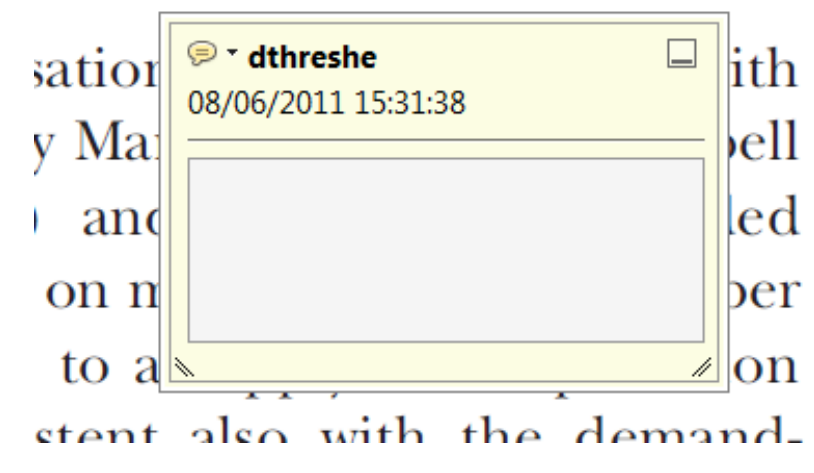

2. Strikethrough (Del) Tool - for deleting text.

Thikes a red line through text that is to be deleted.

\section{How to use it}

- Highlight a word or sentence.

- Click on the Strikethrough (Del) icon in the Annotations section.

there is no room for extra protits al c ups are zero and the number of ret) values are not determined by Blanchard and Kiyetaki (1987), rfect competition in general equilil ts of aggregate demand and supply lassical framework assuming monol eon an evorenois number of firms

\section{Add sticky note Tool - for making notes at} specific points in the text.

\section{Marks a point in the proof where a comment} needs to be highlighted.

\section{How to use it}

- Click on the Add sticky note icon in the Annotations section.

- Click at the point in the proof where the comment should be inserted.

- Type the comment into the yellow box that appears.

lallu allu suppiy silucks. Iviusl ul

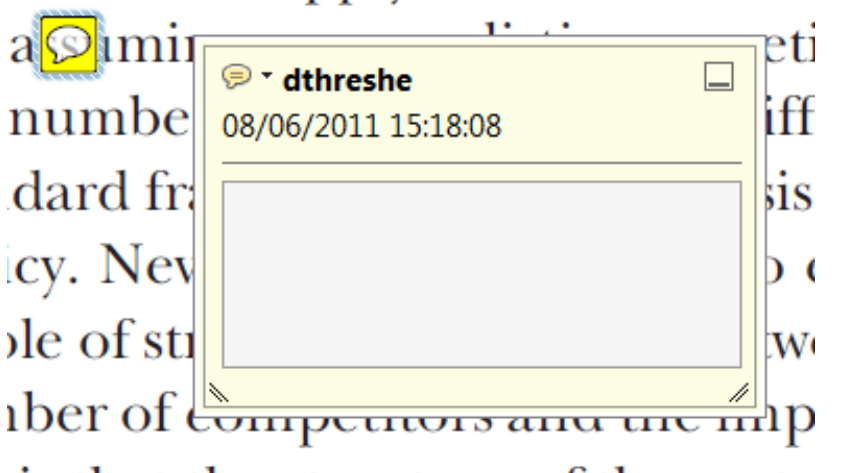

is that the structure of the secto 
5. Attach File Tool - for inserting large amounts of text or replacement figures.

Inserts an icon linking to the attached file in the appropriate pace in the text.

How to use it

- Click on the Attach File icon in the Annotations section.

- Click on the proof to where you'd like the attached file to be linked.

- Select the file to be attached from your computer or network.

- Select the colour and type of icon that will appear in the proof. Click OK.

E N D

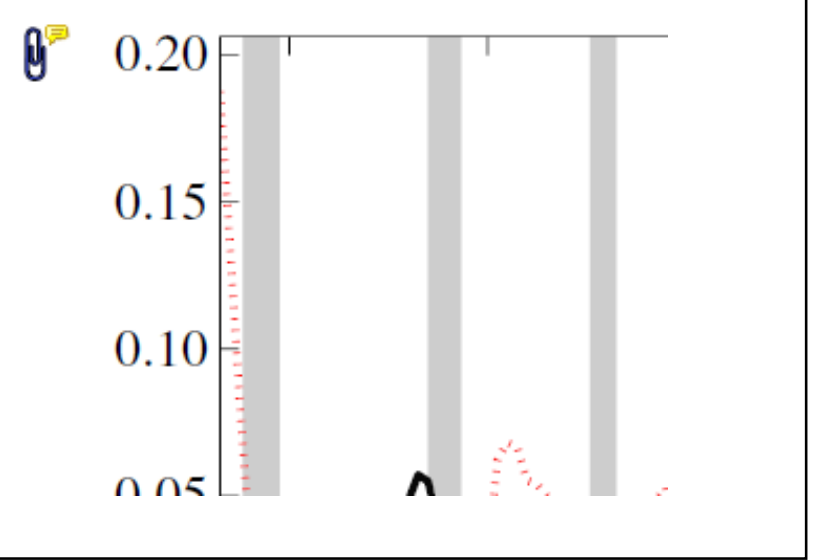

6. Add stamp Tool - for approving a proof if no corrections are required.

- Inserts a selected stamp onto an appropriate place in the proof

\section{How to use it}

- $\quad$ Click on the Add stamp icon in the Annotations section.

- Select the stamp you want to use. (The Approved stamp is usually available directly in the menu that appears).

- Click on the proof where you'd like the stamp to appear. (Where a proof is to be approved as it is, this would normally be on the first page).

of the Dusiness cycie, starting with the on perfect competition, constant ret

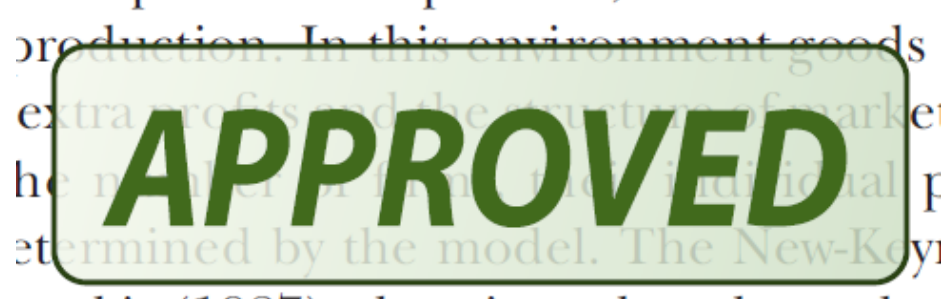

otaki (1987), has introduced produc general equilibrium models with nomin
- Drawing Markups

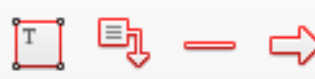

$0 \square \sqrt{6} D$

\section{How to use it}

- Click on one of the shapes in the Drawing Markups section.

- Click on the proof at the relevant point and draw the selected shape with the cursor.

- To add a comment to the drawn shape, move the cursor over the shape until an arrowhead appears.

- Double click on the shape and type any text in the red box that appears.
7. Drawing Markups Tools - for drawing shapes, lines and freeform annotations on proofs and commenting on these marks.

Allows shapes, lines and freeform annotations to be drawn on proofs and for comment to be made on these marks..

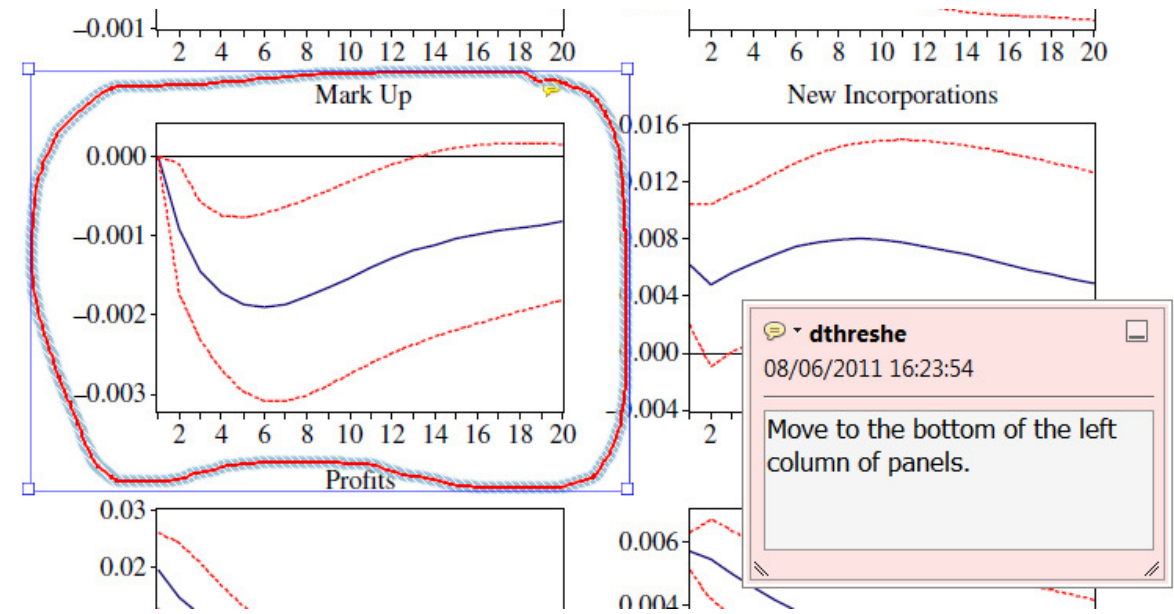

For further information on how to annotate proofs, click on the Help menu to reveal a list of further options:

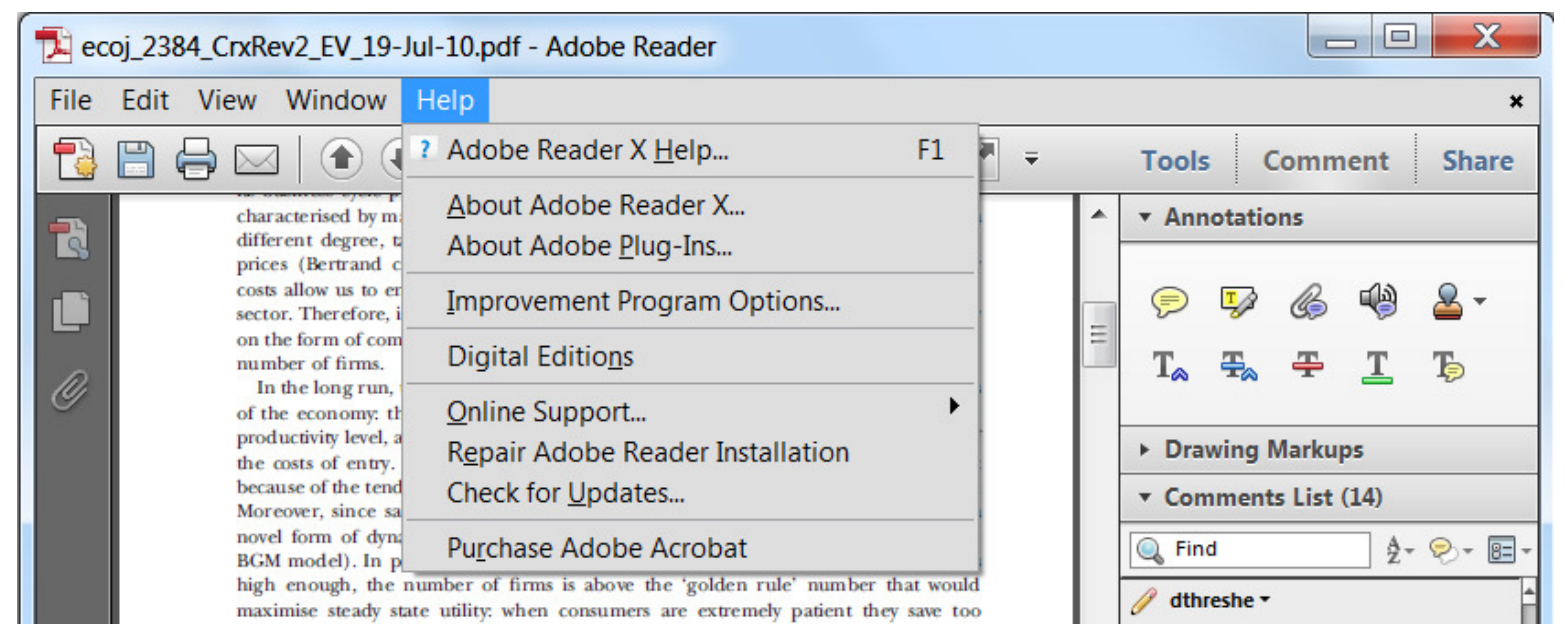

